
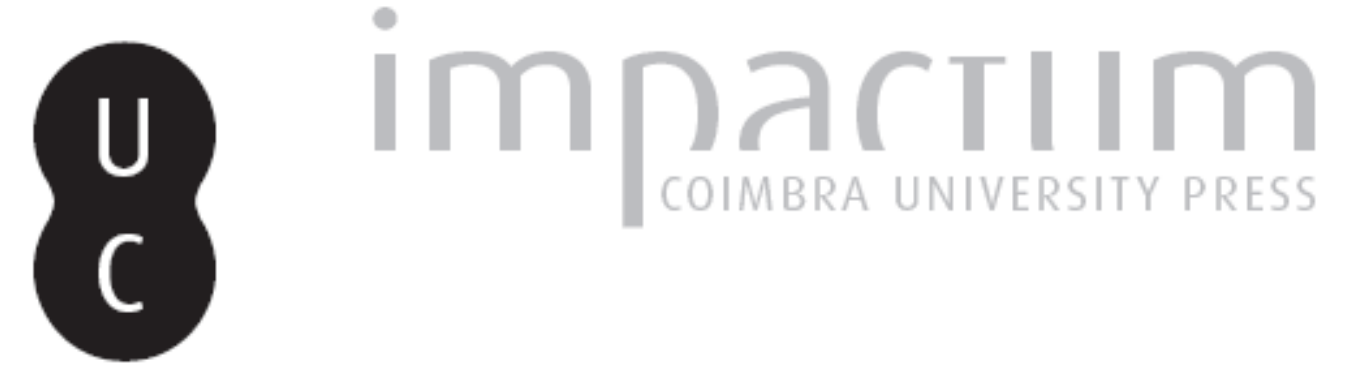

\title{
From Coimbra to Figueira da Foz: field trip
}

Autor(es): $\quad$ Moreira, Claudete; Fernandes, João Luís; Santos, Norberto

Publicado por: Imprensa da Universidade de Coimbra

URL persistente:

URI:http://hdl.handle.net/10316.2/38322

DOI:

DOI:http://dx.doi.org/10.14195/0871-1623_34_12

Accessed : $\quad$ 26-Apr-2023 10:36:05

A navegação consulta e descarregamento dos títulos inseridos nas Bibliotecas Digitais UC Digitalis, UC Pombalina e UC Impactum, pressupõem a aceitação plena e sem reservas dos Termos e Condições de Uso destas Bibliotecas Digitais, disponíveis em https://digitalis.uc.pt/pt-pt/termos.

Conforme exposto nos referidos Termos e Condições de Uso, o descarregamento de títulos de acesso restrito requer uma licença válida de autorização devendo o utilizador aceder ao(s) documento(s) a partir de um endereço de IP da instituição detentora da supramencionada licença.

Ao utilizador é apenas permitido o descarregamento para uso pessoal, pelo que o emprego do(s) título(s) descarregado(s) para outro fim, designadamente comercial, carece de autorização do respetivo autor ou editor da obra.

Na medida em que todas as obras da UC Digitalis se encontram protegidas pelo Código do Direito de Autor e Direitos Conexos e demais legislação aplicável, toda a cópia, parcial ou total, deste documento, nos casos em que é legalmente admitida, deverá conter ou fazer-se acompanhar por este aviso.

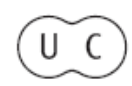




\title{
From Coimbra to Figueira da Foz - Field Trip ${ }^{1}$
}

\author{
Claudete Moreira, João Luís Fernandes e Norberto Santos \\ Centro de Estudos de Geografia e Ordenamento do Território e Departamento de Geografia e Turismo, Faculdade de Letras, Universidade de Coimbra. \\ claudete@ci.uc.pt; jfernandes@fl.uc.pt; norgeo@ci.uc.pt.
}

\section{From Coimbra...}

Coimbra's geographical position (Figure 1) is, simultaneously, strategic and peripheral. This results in a duality of situations that does not help the city's development nor its area of influence. It is evident an investment that seeks to materialize the relations between Oporto and Lisbon Metropolitan areas. However, the relocation of some services has contributed to the drain in diverse administrations: the Directorate of the Turismo Centro de Portugal which is located in Aveiro, the regional delegation of the Portuguese Geographic Institute, which is now located in Castelo Branco, the closing of the Coimbra delegation of the Lusa News, the disinvestment in Metro Mondego. Equally, it are presented, as opportunity drains, the change in the High Speed Train project. Despite Coimbra having a cohesion and cooperation in interurban region polycentrism in Portugal coastal centre region, there is, in fact, a lack of significant increase in investment in promoting the relations between coast and inland (East-West). The central power's concern and the acting of metropolitan areas are intended to give expression to a heavy-headed/two-headed North/South relation making Coimbra's ability for intervention difficult, maintaining weak accesses both to the coastal area and East inland to central Portugal.

The Coimbra Strategic Plan (PEC) (2009), launched in 2005 and associated to with the Deloitte and Vasco da Cunha companies, apart from the definition of the positioning for the national urban network, proposed the identification of the existing factors of excellence (human and cultural capital, scientific and technological poles, health centre, international relationship, gifting of facilities and higher level services). It also underlined the critical and imperative interventions (dynamics of its demographic base, productive reconstitution and social rehabilitation of the historical centre and reinforcement of urban cohesion), aiming to qualify the image of functionality and urban experience (PEC, 2009). The PEC identifies as strategic goals "the integrated development of activities in health, in a dynamic business environment; the region's economic densification, with companies integrating a high level of R\&D, the revitalization of Coimbra as differentiating touristic destination, the urban redefinition of the city, potentiating the current urban voids and privileging the centrality of the Mondego River" (PEC, Base Document, 2009).
The exodus from the city centre is coincident with the historical centre (parishes of São Bartolomeu, Almedina, Santa Cruz and part of Sé Nova, forming a group of parishes). The Lower and Upper town parts, extending towards Celas and São José (Sé Nova parish), present an urban experience with rather different characteristics. The lower town attracts a very eclectic population (pushing away, however, a population with higher incomes that cannot find the products and services it seeks or that is confronted with an uncontrolled environment and some insecurity) given that here are the larger interfaces and exit points of a significant amount of public transport (road and railway). On the other hand, the upper town integrates a significant number of temporary inabitants - university students. Apart from living there, the upper town is also a meeting point for many of the students' nocturnal activities, i.e., students being their main clients. This reality mitigates the reduction in population and the significant ageing of the resident population in this area. However, there are several diverse problems, those associated with noise, alcohol driven behaviour and garbage in the streets being the most significant.

In the internal organization of the city, the green areas are a great plus for Coimbra. As elements of environmental sustainability, they are attended by the population as areas of leisure, walking, rest or sport, being fundamental in the good organization of the urban space and in the quality of the population's living conditions. It must be highlighted the Manuel Braga Park, on the right bank, which together with the Parque Verde, are transforming both banks of the river into a public access space of urban regeneration. Right next to the Republic Square, the Santa Cruz Park, also known as Jardim da Sereia (Mermaid's Garden), has gained a facelift in the past few years with the improvement in accesses and functional revamping both of the existing sports park and in the treatment of sidewalks and integration of the fountain, tea house, restaurant space and sociaising spaces. Still inside the city is the Penedo da Saudade, a space of nostalgia for Coimbra students and a terrace over São José. The garden (neoclassical style) and woods (large diversity of exotic species) of the Botanical Garden (1772), created by the Marquês de Pombal is 13 hectares in area, occupying the south part of the hill.

The symbolic importance of Coimbra is manifested also in town twinning with other cities in several continents. They are: United States: Santa 


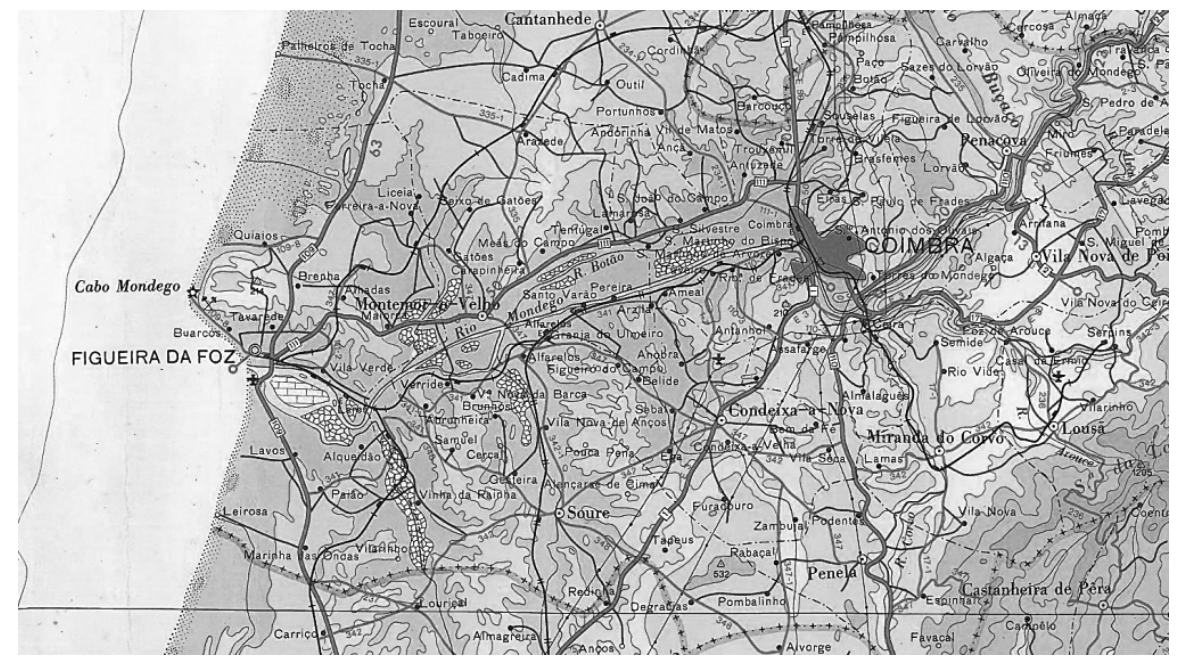

Figure 1

Lower Mondego and surrounding areas. From Coimbra to Figueira da Foz Source: Portugal Chorographic, charter $n^{\circ} 2,1: 400.000$.

Clara, California, Cambridge; Brazil: Santos, São Paulo, Curitiba; Germany: Halle; France: Poitiers, Aix-en-Provence; Spain: Salamanca, Santiago Compostela, Saragoza; Russia: Yaroslavl; Morocco: Fes; Cape Verde: Mindelo; Mozambique: Beira; China: Macao; Italy: Padua; East-Timor: Dili; India: Damão; Luxembourg: Esch-sur-Alzette and Sweden: Lund. This symbolic character is also materialized in the image of the University and of the student parties (Latada and Queima das Fitas) and in the procession in honour of the Queen Santa Isabel, which takes place every two years.

The Portuguese Program for Urban Requalification and Environmental Valuing of the Cities (Polis) arises in Coimbra as the initiative that returned the river to the city. It allowed to integrate, in the historical centre, the Rossio de Santa Clara with the Monastery of Santa Clara-a-Velha and the São Francisco Convent (Conventions Centre and Cultural Space of the São Francisco Convent, 2015) and Portugal dos Pequenitos, a work by Bissaya Barreto and which is clearly one of the most important trademarks of the city of Coimbra. The Polis Program - for urban regeneration around a scarring environmental element and for revitalization of historical centres and its various fields - found a superlative expression in Coimbra. In fact, the Parque Verde of the Mondego gains, in the historical city centre, a statute of leisure centre, sports and culture that offered a new life to this ancient centre.

Both banks became one territory and earned one more icon for the city - the Pedro and Inês pedestrian bridge. The parks linked by this bridge integrate a set of structures and facilities that allow a greater affluence for people. It adds two spaces for exhibitions and museology (Museum of Water and the Portuguese Pavilion at the Hannover Expo 2000, of Modern Art) several leisure and culture events and an immense green space, served by a large parking lot that enables it to be used by a very eclectic population. Connected to all this space of services and leisure in on the left bank is Canção Square, the square for Coimbra academy student parties and several musical events, now with more organized and welcoming facilities.

The historical centre presents other meaningful developments on the Mondego's left bank. This refers to the rehabilitated and revitalized Santa Clara-a-Velha Monastery, an extension of the park's green area. Its surroundings host a weekly antiques' fair and within its walled grounds we find a museum and the complete remains of the monastery's built heritage and of the palace where Queen Santa Isabel lived. These developments are to be joined by the Congress Centre, located in the São Francisco Convent.

The historical centre is also the territory that integrates the places applied to UNESCO World Heritage (Figure 2 ). The process dragged on for 20 years and the restriction of acceptance for applications regarding historical centres, the bulldozer policies of the Estado Novo dictatorial regime in upper Coimbra and the changes undergone in the Páteo das Escolas placed the application at risk. This situation lead to a protocol between the city hall and the University being signed, so that the application was conducted by the University.

The application by the Univer(sc)ity of Coimbra (2004) seeks an identity with the city, integrating elements that marked the city's history, the upper and lower town, the urban regeneration programs, the Metro Mondego project, the university traditions and popular traditions. This project is still associated with Sofia Street with its ancient university colleges which were 22 in total plus 7 monasteries. On June $22^{\text {nd }} 2013$ the University of Coimbra, upper town and Sofia are listed on the UNESCO World Heritage list. 


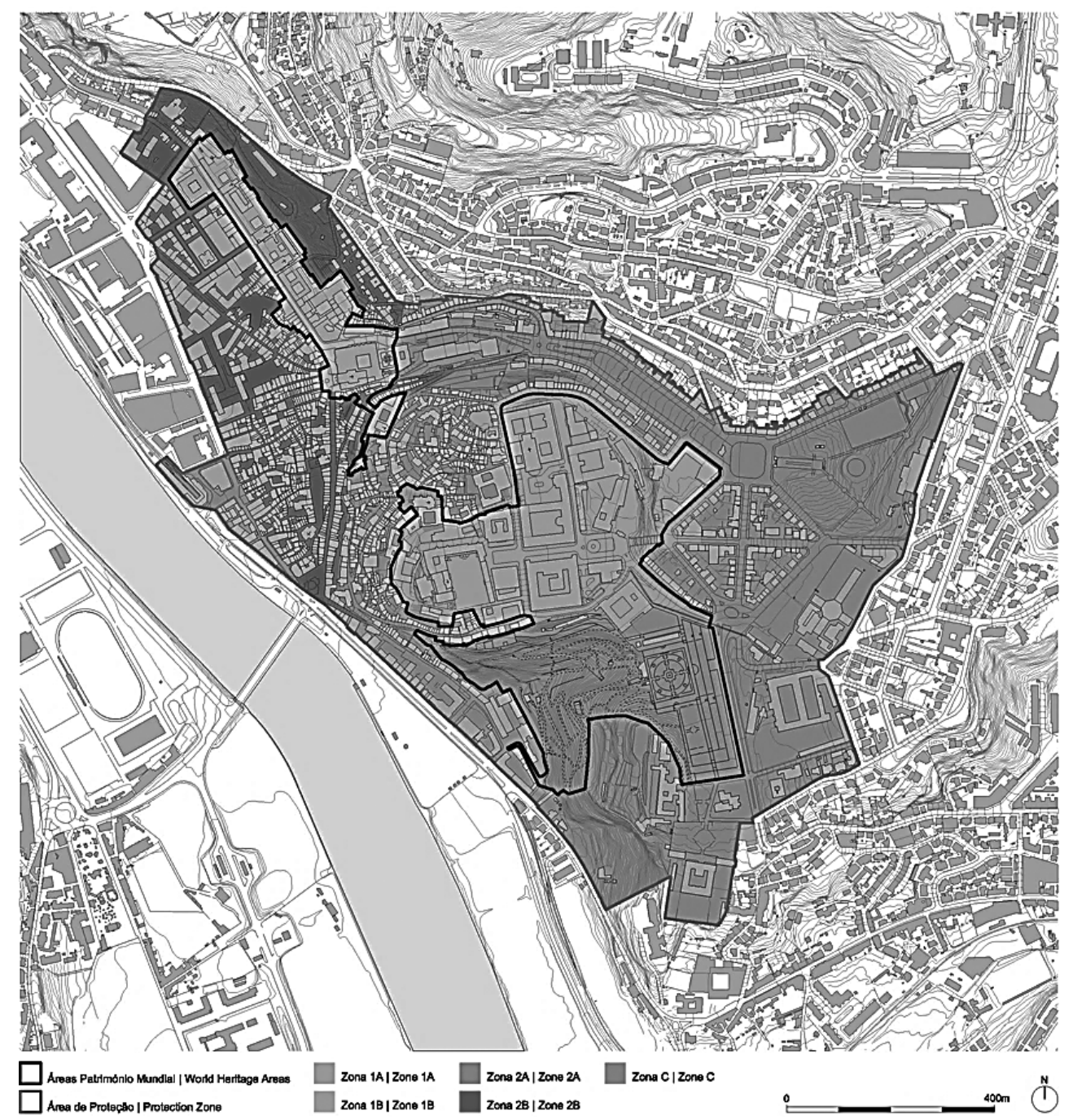

Figure 2

World Heritage Area. Protection Areas

Source: http://www.uc.pt/ruas/monitoring/instruments/regulation

The old city centre, undergoing rehabilitation, has been the base for the diversification and deepening of the touristic offer in the Coimbra area, associated with city-break products and cultural and urban tourism. It seems evident that in the near future, the offer of religious heritage (material and immaterial) will also add meaning as a touristic product through the importance of Santo António and its relationship with the crosiers and the Santa Cruz convent; the valuing of the parties in honour of Queen Santa Isabel, which connects the historical centre between the two banks of the Mondego River, uniting convents; of the presence of the aura of Sister Lucia, anchored in the Carmel of St. Teresa and in the Order of the Carmelites.

And it is also pertinent to mention the city's importance in terms of gastronomy. While linked to its touristic trademark are the traditional roasted suckling pig, the chanfana, the Bairrada sparkling wine and the Tentúgal pastries, the historical centre aggregates a whole diversity of confectionery associated to with convents and a tradition of a cutting edge strategy in the organization of the city and region, with some comparative advantages before new commercial spaces and the emerging polycentrism. The tradition, identity and increase of the participating experience are funding innovative elements that, by using the monumental heritage built and immaterial - foster a cultural and recreational density of superlative quality that makes the urban historical centre a product simultaneously of tradition and innovation.

The Mondego River is the largest water course flowing entirely within Portuguese territory. Located 
in the centre of mainland Portugal, the Mondego River has its spring in the Northern slope of Serra da Estrela, next to the village of Manteigas, at about $1.547 \mathrm{~m}$ of altitude, running into the Atlantic Ocean, South of the Cabo Mondego and of the city of Figueira da Foz.

The course of its bed extends for about 253 $\mathrm{km}$. Throughout its course, the Mondego River crosses formations of two important structural units: the Massif Central (also known as Iberian Massif Central or Hesperic Massif) and the Western Meso-Cenozoic Fringe, draining a relatively symmetric hydrographic basin, oriented from North-east to South-west of approximately $6659 \mathrm{Km}^{2}$.

The Mondego River has as main tributaries, on the right bank, the River Dão (which drains, with its tributaries and sub-tributaries, part of the Serra do Caramulo) and, on the left bank, the River Alva (which drains the precipitations and snow melting from Serra da Estrela), the River Ceira (into which are drained the precipitations that occur in Serra de S. Pedro and Serra do Açor), the River Arunca and the River Pranto. While the first two are located in the Upper and Medium Mondego, the latter two are located in the Lower Mondego.

In the final section of the hydrographic basin, in the Lower Valley and Lower Mondego Valley, extending downwards from Coimbra to Figueira da Foz, in an extension of about $48 \mathrm{~km}$, the Mondego River is spread for its alluvial lowland, near its base level, in a lowland developing until near Figueira da Foz.

In this lowland the gradient is very poor, practically nil. This happens after the river upstream runs through relatively narrow and deep valleys and with a course full of meanders through the land of the Massif Central. In the Lower Mondego there are stiIl some hills and small plateaus. From Portela to Figueira da Foz it is developed the Mondego basin's dejection cone. It is a paleovalley formed in limestones and sandstones that would have probably been originated in the regression that accompanied the Würm glaciation.

Secularly it was nececessary to cut the arboreal vegetation and burn the herbaceous and shrubby vegetation, upstream of Coimbra, upriver in the Medium and Upper Mondego basin. These activities were accentuated with the need to obtain land for the growing of cereals and, later, with the need to obtain wood, raw material used in naval construction. Thus, the steep slopes in the Upper and Medium Mondego became more exposed to the eroding agents.

Throughout around eight centuries transportation of solids was growing in the Upper Mondego (where the Mondego is a mountain river), but mostly in the Medium Mondego, rendering the silting of the Lower Mondego inevitable.

The changes of the Mondego River regime became notable in the late $12^{\text {th }}$ century, beginning of the $13^{\text {th }}$ century and started being reported, at least, since the $14^{\text {th }}$ century, becoming a problem which ran through centuries. Throughout several centuries there were several royal and government measures, there were several dispositions filled, sometimes to safeguard, other times to degrade, but almost always to improve the river's regime and safeguard the fields of the Mondego. There were determined constraints to several activities, that were instituted positions, requested studies, made projects and executed works, in which were inserted the creation of the Mata do Choupal. Despite the mitigation resulting from the man-making of the valley, flooding still occurs today on a regular bass.

The secular flooding occurs as the soil adjoining the Mondego River present an unique agricultural aptitude in the country, integrating an extensive alluvial plain where the river has set and that was settled and built. These specificities of the river's regime led to this sub-region having the first hydroagricultural facility in the country, constituting today as an area of high potential for agricultural production.

The hydraulic engineering works integrated in the hydric development of the Mondego hydrographic basin have started in 1972 with the construction of the Aguieira Dam. The construction allowed the control of the Mondego River water flows and the solid flows. It must be added that by retaining the sediments in the reservoirs, river and estuary silting was minimized and farmland loss was reduced.

Besides that, the agricultural use of the valley was made viable by enabling the increase of larger extensions of temporary irrigated farming which are implanted throughout the valley and, in a very appreciable way, the reforming of fields downstream of the city of Coimbra.

It must be stressed that in 1970 and 1971 an update of the preliminary draft of the Lower Mondego regularisation was made. The reorganization and regularization of the hydrographic system in the Lower Mondego and the hydraulic exploitation implied interventions upstream in order to avoid "drama in the lowland", so well described by Fernandes Martins (1950). In this scope, multiple differentiated interventions were contemplated throughout the hydrographic basin of the Mondego River. In the Medium Mondego the Aguieira Dam, Raiva Dam, Fronhas Dam and the Fronhas-Aguieira derivation tunnel. Downstream from Portela the construction of the Weir-Mondego Bridge of Coimbra and the general conductor canal. It is from the weir that the derivation of water for the irrigation canals in the Lower Mondego is obtained and that water is transported for supply, namely, industrial. To these interventions it must be added the interventions in the estuary area, which were important to enable navigability in the Figueira da Foz Commercial Port and in the terminal section of the centre bed until the confluence with the Foja River.

It is in the scope of the General Plan for Hydraulic Use of the Mondego Basin that is encompassed the Lower Mondego Hydroagricultural Project. This hydro-agricultural exploitation project of the Mondego Valley or Lower Mondego Subsystem contemplated a development and agricultural restructuring which implied: the distribution of properties to resize the parcels of exploitation; the levelling of 
soils; draining the land; the creation of a new irrigation system, the primary drying networks and peripheral beds to protect the irrigated areas against the intrusion of outside waters; a roadway access system; the reconversion of the agriculture practised in the Mondego fields, having the concern not only to select quality seeds but also experiment and insert other growing species aiming to make agriculture in Lower Mondego more modern and competitive.

The sub-region of Lower Mondego is characterized for having a mild climate with Mediterranean characteristics, i.e., it evidences a moderately warm and dry summer with the winter also mild.

Among the geographical elements that must be highlighted:

(i) the contact with the ocean (on the extensive Atlantic coast)

(ii) the Serra da Boa Viagem (a topographic accident with a West-Northeast East-Southeast orientation that exceeds $250 \mathrm{~m}$, i.e., it achieves the highest level of 258m in Bandeira);

(iii) the longitudinal penetration of the Lower Mondego valley (a valley with a West-East orientation and therefore open to oceanic orientation);

(iv) the meridional and northern penetration of the valleys of the Mondego tributary rivers as well as (v) the barrier that constitutes the Coimbra Marginal Massif.

The lower adjective does not find full morpho-structural sustainability because the sub-region presents itself flattened in its dorsal valley and also arises with a steep topography, being punctuated by some important slopes, from which the Serra da Boa Viagem is the most significant.

On the edge of the vast alluvial lowland that is drawn in the Lower Mondego there are river terraces. During the Quaternary period the succession of glaciar and interglaciar periods led to a shift in the base level which is the cause of today's terraces. Besides that, there are low altitude plateaus and hills. These are sandstone hill formations developed from the pliocene maritime surface and transgressions that took place in the late Pliocene or even in the Quaternary. The altitudes are relatively low, between $50 \mathrm{~m}$ and $200 \mathrm{~m}$. A topographic dichotomy is very much apparent, which finds local translation in the expressions field and hill. The sub-region is individualized in the national territory for having a landscape that is defined by an extensive agricultural area which is the Campos do Mondego (Fields of the Mondego). It is an agricultural surface with high productive potential. The alluvial lowland of the Mondego River is dominated by the rice cultures. The flooding of the fields, which conditioned the practice of autumn-winter cultures, led to the adoption of cultures with a shorter vegetation cycle and, in this context, rice turned out to be a viable culture, despite the particular and local climate conditions of the Lower Mondego not being in favour of this culture. Still, since the $19^{\text {th }}$ century, by the mouth of the Rivers Arunca, Foja and Pranto, growing rice is a way to avoid the flooding. In the valley of the Lower Mondego large agricultural units were established towar- ds rice production: Quinta da Foja, Quinta do Seminário, Quinta da Boavista and Quinta do Canal are a few examples. These exploitation units were always orientated towards an industrial agricultural production.

The rice, namely carolino, is commonly found in the region's gastronomy (duck rice a la Mondego, cabidela rice, lamprey rice, seafood rice, sweet rice, for example) being safeguarded and disseminated by the gastronomy associations movement (there is, for example, the Confraria Gastronómica do Arroz e do Mar - Gastronomy Association of the Rice and Sea located in Figueira da Foz) and some gastronomy events (for example the Rice and Lamprey Festival in Montemor-o-Velho). It is indisputable the importance that rice growing has in gastronomy, landscape and in the identity of the sub-region.

The agricultural practices in the Lower Mondego always sought to adapt to the unique characteristics of the valley, even if it meant compromising the agricultural outcome. Sometimes, the bogs rendered the soils unproductive. The difficulties in drying the fields delayed the seeding until the months of July and August. It could be anticipated in dryer years, but could almost always be grown in a short period of time or using cultures with a short vegetation cycle.

In the Fields of the Mondego the landscape is marked by the geometry of the agricultural fields and by alignments of rupicola formations which border watercourses where there are ashes, poplars, willow and alders. The agricultural fields of the main valley and of the secondary valleys take the name of the surrounding areas which adjoin the river and their tributaries, for example: Campo da Geria, Campo do Ameal, Campo de Arzila, Campo de Tentúgal, Campo de Montemor, Campo de Maiorca, Campo da Ereira, among others.

The field, a frequently flooded area, is occupied with irrigated crops. The hill or serra is a non-irrigated area in which the population is protected from the irregularities of the Mondego River flow will be implanted and grown.

In 1986, with Portugal joining to the then European Economic Community, it is appreciable, in terms of occupation of soils, the territorial expression of wine growing (Figure 3), especially to the North, a production which takes place in the delineated region of Bairrada. In terms of occupation of soil it is important to highlight that the sub-region is punctuated by small industrial cores, business parks and logistics platforms whose location finds in the accesses - namely road junctions and main port, railway and roadway infrastructures - the leitmotif for implantation and growth.

\section{to Figueira da Foz}

Already in the second half of the $19^{\text {th }}$ century, and during a large part of the $20^{\text {th }}$ century, Figueira da Foz was the arrival point of populations from different social levels coming mostly from Portugal's 


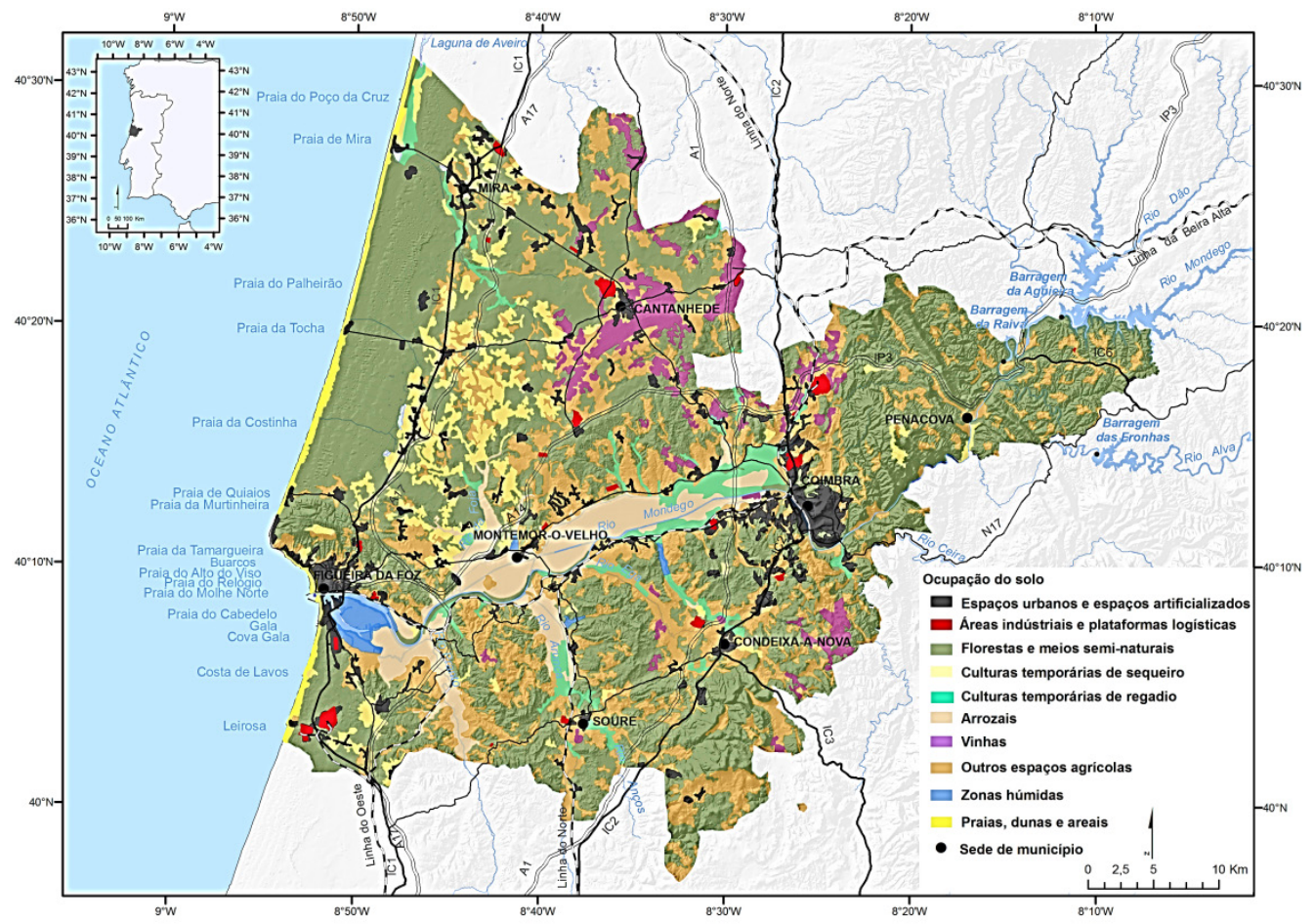

Figure 3

Occupation of the soil in the sub-region of Lower Mondego

Source: Produced by Claudete Oliveira Moreira (2013) based on Corine Land Cover 2006, Portuguese Environment Agency, Lisbon.

central region, from popular vacationers to a certain rural bourgeoisie from the Beiras region who, following the Mondego valley, went there to bathe, remaining in the city for a significant part of the summer, from June to September.

This was the railway era, traditional connection point from the city to the inland territories. Figueira da Foz was also the beach for Coimbra's elite, apart from being the most accessible for Spanish tourists living near the border.

This conjugation of demands, as well as the proximity with Coimbra, created a very particular bathing area like environment, with an everyday life associated with enjoying the sea and daily use of the beach, walking through the streets and oceanic sidewalks and visiting the casino - the so called Peninsular Casino, a house for gambling and shows, and one of Figueira da Foz's touristic promotion trademarks.

As a port and fishing territory, Figueira da Foz gradually rose as a place of enjoyment and leisure, a place for receiving tourists, a place of sun and beach in the period during which tourism has progressively intensified in Portugal.

However, with the loss of the strategic relevance of the train and the increase in the importance of individual transportation and car; with the reduction of distances, time and cost, firstly regarding the Algarve and Southern Spain and afterwards destinations such as the Caribbean or Brazil, this cold watered beach lost its centrality.

Still, with around 62 thousand inhabitants in the whole municipality (according to data from 2011, it was the second largest populated municipality of the Lower Mondego after Coimbra), Figueira da Foz is still a destination of sun and beach with a regional influence.

Mostly in the city and in the vicinities of the beaches of Claridade and Buarcos, Figueira da Foz has an urban landscape marked by seasonality and strong incidence of secondary residences, in particular owners with their main residence in Coimbra.

Despite that, the new geography and new mappings of tourism in Portugal and in the Iberian Peninsula, the relative position of Figueira da Foz slowly devalued and accelerated its disqualification as a destination for sun and beach.

Aware of this trajectory, but without driving away from the sea, the most recent investments in tourism in Figueira da Foz have diversified the offering.

On the one hand, it is seen in valuing the recreation marina - recent numbers indicate, in this marina, 155 resident mariners and 683 annual/pass ers by. On the other hand it is bet seen in the regeneration of the bathing areas and use in the different beaches in the municipality. Besides, it has been verified that there has been some investment in 
nautical sports, with special relevance to disciplines such as windsurf, surf, sailing or bodyboard, using some of the climate features, like the number of intensely windy days or the average wave height.

Aiming at mitigating the seasonality and requalifying its touristic image, the municipality has valued potentials such as the natural and cultural heritage, taking the value of geodiversity (from the sea to the dune landscapes and to the limestone hills) and its forming and educational role, directed not only for the tourism market but also for the resident population.

In this point of view, it must be highlighted the values associated, on one hand, to the Mondego estuary and, on the other hand, the potential released by the wider and more sustainable appropriation of the Serra da Boa Viagem that, to the North, frames the city that is head of the municipality.

In the Mondego estuary and sedimentary island of Morraceira, it must be highlighted the salt pans, in the past an important activity for the local economy but now a heritage and a distinctive value that attempts are now made to preserve.

With a landscape dominated by small parcels, a system of cannals and a set of wood structures used to store salt, this salt pans' ecosystem is now a touristic and learning territory which promotes education towards sustainability and is for the defence of biodiversity and geodiversity. A museum was created, pedestrian circuits were formed and conditions for bird watching were created.

In terms of cultural heritage, the city and the municipality have still invested in local gastronomy especially, in the case of some events, events directed towards sea dishes such as seafood, sardines or mackerel.

However, the city has also invested in recovering and requalifying historical and cultural facilities and buildings, civilian or military, such as Casa do Paço, Sotto-Mayor Palace, Sta. Catarina Fort, Buarcos Fortress and Municipal Museum Dr. Santos Rocha.

Alongside the Centre of Arts and Shows (opened in 2002 with 2 auditoriums and several exhibition rooms), the city provides some cultural offer, distributed throughout the whole year but focusing especially in the organization of music festivals for young people (like the Sunset), mostly in the summer.

Tourism diversification in Figueira da Foz, mostly with an ecotourism and adventure sports side, presents another interesting feature: the Serra da Boa Viagem. As a limestone elevation and a maximum altitude of 260 meters, this is a space for leisure and recreation both for the local population and for tourists and visitors.

In this hilly space, the geologic heritage must be highlighted like the geomonument of the Cabo Mondego, a feature classified and protected by the relevance of the stratigraphic sequence of the Jurassic that can be seen there. Apart from this natural monument, the focus is still on the lagoon water spaces - the lagoons of Vela, Braças and Salgueira, endorheic lagoons of special landscaping and biodi- versity interest, especially due to the presence of aquatic birds, such as several species of ducks.

Another superlative value of the Serra da Boa Viagem is in the vegetation cover. As a land where there already have been forest fires, this area has been subject to reforestation programs. As in the Morraceira and also in the estuary, it has also been invested in the line of education towards sustainability, for one part of that strategy of reforestation has benefited from the participation of school institutions and others.

The current Serra da Boa Viagem Forest Park has around 400 hectares covered by species like pinus pinaster and the Portuguese cypress (Cupressus lusitania).

In terms of surface, the municipality of Figueira da Foz is the second largest in the central region with a total area of $379.4 \mathrm{~km}^{2}$. From that extension, forests occupy about $57 \%$ of the total, while $24 \%$ of land has uses in the domain of agriculture that is distributed according to the different sectors of the municipality between rice growing, irrigation and non-irrigation crops.

From a strategic point of view, the forest occupies a relevant position in the municipality's economy, mainly for the presence, in its Northern sector, of two paper pulp production industries: the factories of the Celbi and Soporcel/Portucel groups, which use local and non-local, national and international raw materials, mainly eucalyptus.

Despite the industrial crisis, which also affected the city and the municipality - as verified with the closing of the naval repair shipyards (in 2011 ) and the closing, in 2013, of a cement extracting industry (hydraulic lime) from the company Cimpor - the secondary sector still resists, especially in an industrial park which, to the South, in the area of Lavos, the clearing of the forest extension in that area.

In fact, in one of the rural parishes of the South sector of Figueira da Foz (Marinha das Ondas), it is located the head office and central facilities of one of the most important food industries in the country - Lusiaves, leader in the distribution of poultry, mainly chickens, one of the meats most consumed in Portuguese cuisine.

Despite that territory presents a stronger image connected to tourism and services (currently, about $65 \%$ of the active population is in the tertiary sector), $31.6 \%$ of employment is associated with the industrial sector, while in agriculture and remaining activities of the primary sector that value does not exceed $3.5 \%$, a statistic that reflects the regional and national dynamics.

That low value in the primary sector is also witness to the loss of importance of the national and local fishing sector. In spite of that, according to data from 2013, in the Figueira da Foz fish market there were sold 5.3 million $\mathrm{kg}$ of mackerel, 3 million $\mathrm{kg}$ of sardine and 1.3 million $\mathrm{kg}$ of horse mackerel (the three main species caught in this fishing port, data contrasting with Aveiro and Mira - other fishing 
ports in the vicinity, in which mainly horse mackerel are caught and sold).

As the city's entrance and exit of products, the Figueira da Foz port is one of the 7 main port infrastructures in the country, together with - from North to South - Viana do Castelo, Douro/Leixões, Aveiro, Setúbal and Sines. However, with a problem of shallow depth of its coast (which prevents the docking of ships with larger capacity), the port of Figueira da Foz (with only $2.3 \%$ of the total cargo in 2014) is far from being able to compete with the ports of Sines (more than 40\%), Douro/Leixões (a volume of more than $20 \%$ of the total) and Lisbon (about 15\%), the country's three main ports.

In spite of all of that, and from a strategic point of view, Figueira da Foz is in the meeting point between the Atlantic and the Mondego, between the maritime extension and the river corridor which always connected the geoeconomies of the sea with the inland territories of the central region of the country. Therefore, investment in the social and territorial cohesion and in the connectivity with the exterior, Figueira da Foz intends to claim itself as a territory of articulation between the Mondego valley and the Atlantic, between the rice cultures and the forest, and between the landscapes and everyday lives of fishing, port life and use of the sea, in articulation with the ecotourism, heritage and environmental values of the limestone in Serra da Boa Viagem and its adjacent forest and lagoons.

In this municipality there are classified and protected landscapes, like for example the "natural monument of the Cape Mondego" and the "classified location of the Santa Olaia and Ferrestelo areas", integrated in the Portuguese Network of Protected Areas, and the "Quiaios dunes ecosystem" - located North of the Serra da Boa Viagem, with an extension, throughout the coast, of $12 \mathrm{~km}$ (and an approximate width of $6 \mathrm{~km}$ ), between the villages of Quiaios and Tocha (the latter belonging to the municipality of Cantanhede).
However, the landscape values constitute a permanent challenge and a constant alert: the multifunctionality and promiscuity of landscape uses; the risk of summer fires in the forest areas (constituting a threat to its diversity) and a tendency for the extension of single vegetable cultures (to which is no stranger the presence of industrial units of cellulose fibres); the risk of eutrophication of the so called lagoons in Quiaios (the Vela, Braças and Salgueira lagoons); as well as the erosion that, in Figueira da Foz as in other sectors of the Portuguese coastal areas, affects the coastal areas, constitute relevant challenges for the development of this territory that, in this or other perspectives, should not be ignored at a municipal scale.

\section{References}

MARTINS, A. F. (1950) - "O drama da planície. Breves notas para uma palestra acerca dos Campos do Mondego". In ALVES, A. A. da S. (ed.) - Boletim comemorativo do décimo aniversário do Ateneu de Coimbra. Coimbra, Ateneu de Coimbra, pp. 6-19.

MOREIRA, C. (2013) - Turismo, território e desenvolvimento competitividade e gestão estratégica de destinos. Dissertação de Doutoramento. Coimbra, Universidade de Coimbra.

SANTOS, N. (2013) - "Coimbra: a organização da cidade e o centro histórico urbano". In FERNANDES, José Alberto e SPOSITO, Maria Encarnação (orgs.) - A nova vida do velho centro nas cidades portuguesas e brasileiras. CEGOT, Porto.

VASCO DA CUNHA/DELOITTE (2009) - Plano Estratégico de Coimbra. Coimbra, Câmara Municipal de Coimbra. 